\title{
Milk production characteristics in Southern Brazil
}

\section{Características da produção de leite no Sul do Brasil}

\author{
Tony Picoli ${ }^{1}$; João Luíz Zani²; Cristina Mendes Peter³; Victor Fernando Büttow Roll'; \\ Maria Edi Rocha Ribeiro5; Gilberto D’Ávila Vargas²; Sílvia Oliveira Hübner²; \\ Marcelo de Lima $^{2}$; Geferson Fischer ${ }^{2 *}$
}

\begin{abstract}
This paper aimed to describe milk production in Southern Rio Grande do Sul state, Brazil, and to identify factors that affect milk quality at this region. The average age of regional dairy farmers is 49 , and $67.9 \%$ has not concluded elementary school. Dairy farming is carried out on properties with an average of 26.06 hectares and 8.4 lactating cows. Most of them $(32.83 \%)$ yield 50 to $100 \mathrm{~L} /$ day. Among the properties, $13.21 \%$ yield up to $30 \mathrm{~L} /$ day, and only $1.89 \%$ produces over 500 milk liters a day. Average yield was $6.8 \mathrm{~L} /$ day. Regarding to milking procedure, $39.3 \%$ farmers milk manually the animals, only $14.2 \%$ performed pre-milking teat disinfection, and $53.9 \%$ uses a single cloth to dry all animal teats. For infrastructure, $52.8 \%$ milks animals in wooden cowsheds. We observed that the average somatic cell count (SCC) was within legal parameters, presenting negative correlation with milk production $(r=-0.23)$ and lactose content $(r=-0.39)$. However, the total bacterial count (TBC) was above legal parameters. Education level seems to interfere in management and milk quality, because the less educated groups are, the less adequate are infrastructure, management, and product quality. Data show that there is a lower quality milk production where poor management techniques are adopted and owner education level affects milk quality.
\end{abstract}

Key words: Milk quality, small farmer, milking, education

\section{Resumo}

Este trabalho teve como objetivo descrever a produção de leite no Sul do Rio Grande do Sul, Brasil, e identificar os fatores que afetam a qualidade do leite na região. A idade média dos produtores de leite da região é de 49 anos, e 67,9\% não concluíram o ensino fundamental. A atividade leiteira é realizada em propriedades com média de 26,06 hectares e 8,4 vacas em lactação. A maioria dos produtores $(32,83 \%)$ produz entre 50 a 100 litros de leite por dia. Entre as propriedades, 13,21\% produz até $30 \mathrm{~L} /$ dia, e apenas $1.89 \%$ produz mais de 500 litros de leite por dia. A produtividade média foi de $6,8 \mathrm{~L} / \mathrm{vaca} / \mathrm{dia}$. No que diz respeito ao procedimento de ordenha, $39,3 \%$ dos produtores de leite ordenha seus animais manualmente, apenas $14,2 \%$ realizam desinfecção dos tetos antes da ordenha, e 53,9\% usa um único pano para secar todos os tetos dos animais. Com relação à infra-estrutura, $52,8 \%$ dos produtores ordenham seus animais em estábulos de madeira. Observou-se que a contagem média de células somáticas (CCS) ficou dentro dos parâmetros legais, apresentando correlação negativa com a produção de leite $(r=-0,23)$ e teor de

1 Discente de Doutorado em Veterinária, Universidade Federal de Pelotas, UFPel, Pelotas, RS, Brasil. E-mail: picolivet@gmail.com

2 Profs. Drs., Dept ${ }^{\circ}$ de Veterinária Preventiva, UFPel, Pelotas, RS, Brasil. E-mail: jluizzani@ig.com.br; gdavilavargas@gmail. com; sohubner@yahoo.com.br; mdelima.ufpel@gmail.com; geferson.fischer@gmail.com

3 Residente em Saúde Coletiva, UFPel, Pelotas, RS, Brasil. E-mail: cristina_peter@hotmail.com

4 Prof. Dr., Dept ${ }^{\circ}$ de Zootecnia, UFPel, Pelotas, RS, Brasil. E-mail: roll2@hotmail.com

5 Pesquisadora, Empresa Brasileira de Pesquisa Agropecuária, EMBRAPA, Clima Temperado, Pelotas, RS, Brasil. E-mail: maria. edi@cpact.embrapa.br

* Author for corrspondence 
lactose $(r=-0,39)$. No entanto, a contagem bacteriana total (CBT) ficou acima dos parâmetros legais. $O$ nível de escolaridade parece interferir na adoção de técnicas adequadas de ordenha e, consequentemente, na qualidade do leite, porque os produtores menos instruídos trabalham em uma infra-estrutura mais precária e obtém um produto de menor qualidade. Os dados mostram que há produção de leite de menor qualidade em estabelecimentos onde o nível de escolaridade do proprietário é baixo e são adotadas técnicas inadequadas de manejo de ordenha. Portanto, a instrução do proprietário afeta a qualidade do leite.

Palavras-chave: Qualidade do leite, pequeno produtor, ordenha, educação

\section{Introduction}

Brazilian milk production has significant socioeconomic importance; the country is the fifth largest producer, and in the first quarter of 2013, raw milk production was 6,186 billion liters (IBGE, 2014). According to estimates, milk production is expected to grow $1.9 \%$ per year; and, in 2023, should exceed 41.3 billion liters (BRASIL, 2013). Milk production is present in various Brazilian cities and is highlighted by job creation and regional income generation. Familiar agriculture accounts for a significant share of national agriculture production; and understanding production system scenarios in farms allows rural setting of goals for production optimization and improving farmer incomes.

In general, Southern Brazil farmers face milk production as a complementary activity of other property venture, which has direct impact on activity yield being very small (SCHNEIDER, 2003). In Milk Producer Units (MPU) with small area, as is the case with most farms in Southern Brazil, milk production is the activity performed in relation to animal production (BALBINOT JUNIOR et al., 2009).

A major cause of milk yield reduction is mastitis (KUMAR et al., 2010). It occurs due to changes in secreting epithelial cells and alveolus vascular permeability during infection. The scale of loss is influenced by the infection severity, causative microorganism type, duration, animal age, season, nutritional status and genetic potential (SCHULTZ, 1977).
One of the most used tools for milk quality monitoring is the Somatic Cell Count (SCC), which encompasses all milk cells, especially the defense ones, which increases in an infection process. Through SCC is possible to measure mastitis index in or inflammation severity in a single animal analysis (OLECHNOWWICZ; JASKOWSKI, 2012). The TBC (Total Bacterial Count) is another parameter taken into account for current local law to assess milk quality; mainly, related to the milking process hygienic conditions and equipments used to store the product (BRITO et al., 2002; BRASIL, 2011). According to recent national law changes (BRASIL, 2011), milk quality becomes an important tool for dairy production system management, and one of the parameters to assess milk production efficiency.

We aimed to characterize the dairy production systems in Southern Rio Grande do Sul state, Brazil, as well as to identify affecting factors for local milk quality.

\section{Material and Methods}

We visited, in 2012, 274 Milk Production Units (MPU) in Southern Brazil, in the Southern region of Rio Grande do Sul state, including the microregion of Pelotas and of Coastal Lagoon in order to obtain sufficient data to characterize each MPU and also collect milk samples for quality analysis. Data was obtained with the application of epidemiological questionnaires to milk producers. Respecting the number of MPU in region and the sample leap set were randomly 
selected 274 MPU, where an epidemiological questionnaire was applied and sought a simple and straightforward way, identified the characteristics of the production system and, addressed topics such as the characterization of the owner, of the property and production, with emphasis on the process of milking equipment, hygiene and animal handling.

From each MPU were aseptically collected in suitable containers, two milk samples from cooling tank, after proper product homogenization. The samples were sent under refrigeration to the Milk Quality Laboratory of the Brazilian Agricultural Research Corporation - EMBRAPA - Temperate region, where TBC and SCC were performed by flow cytometric analysis in automated equipment (Bentley Instruments, Inc. Minessota, USA). Lactose content, fat, protein and total solids were obtained by infrared spectrophotometry. TBC and SCC were transformed to base 10 logarithm and analyzed using the Levene test for sample homogeneity determination. Pearson correlation coefficients of TBC, SCC, fat content, protein, lactose and total solids in milk were obtained and compared to each other through Statistical Analysis System software (SAS INSTITUTE, 2004).

\section{Results}

The average area of 274 MPU in Southern Brazil was 26.06 hectares, of which $50.2 \%$ is smaller than 20 hectares. The average lactating animals was 8.4 cows, and $73.6 \%$ of the units have less than 10 cows in production, and $26.8 \%$ less than five animals.

Concerning the amount of produced milk, $13.21 \%$ of the units produce up to 30 liters per day; $21.13 \%$ between 30 and 50 liters a day; $32.83 \%$ from 50 to 100 liters; $20 \%, 100$ to 200 liters; $10.94 \%$, between 200 and 500 liters; and only $1.89 \%$ produces over 500 liters per day. In our survey, the average yield was $6.8 \mathrm{~L}$ per cow a day.

With respect to mastitis diagnostic tests, only $12.45 \%$ respondents perform shallow dish with a black bottom test; however, a few number determined the test frequency. As for California Mastitis Test (CMT), 47.55\% respondents said making use; yet a few number frequently use for subclinical mastitis screening purposes, which shows an information deficit about disease control. Overall, only $5.66 \%$ respondents performed daily some diagnostic tests, and include alcohol test carried out by dairy industry at collection moment, with mastitis diagnostic test.

Currently, the major part of MPU from Southern Brazil milk their animals mechanically (60.7\%), reaching a daily average production of 133.9 liters per day, with an average yield of $12.8 \mathrm{~L}$ per cow a day. Producers, who still carry the milking handly (39.3\%), have average daily production of only 51.3 $\mathrm{L}$ a day with average yield of $9.7 \mathrm{~L} / \mathrm{cow} /$ day. Even when they use mechanized milking, which would facilitate work and prevent mastitis in herd as wellhandled, $52.8 \%$ still performs the procedure in wooden cowsheds, and $36.3 \%$ of cases still milking their animals over dirt floors.

In the local studied area, the owner average age was 49 years and the great majority has not completed elementary school $(67.9 \%)$, and $4.2 \%$ are illiterate, $7.6 \%$ started high school, but only $3 \%$ completed and only $1.1 \%$ developed college education. Farmers were divided into two major groups called: group 1 (illiterate, incomplete and complete elementary education) and group 2 (incomplete high school education and college education) for education level analysis. We found that farmers with less education had lower percentages of adopting optimal management techniques, while such techniques are most adopted among higher education level producers. The results are shown in Table 1. 
Table 1. Handling and infrastructure of milking in milk production units in Southern Brazil $(\mathrm{n}=274)$.

\begin{tabular}{|c|c|c|c|}
\hline & & $\begin{array}{l}\text { Group } 1 \\
(n=250)\end{array}$ & $\begin{array}{c}\text { Group } 2 \\
(n=24)\end{array}$ \\
\hline \multirow{2}{*}{ Milking } & manual & $41,9 \%$ & $19 \%$ \\
\hline & mechanized & $58,1 \%$ & $81 \%$ \\
\hline \multirow{2}{*}{$\begin{array}{c}\text { Teat } \\
\text { desinfection }\end{array}$} & YES & $14,6 \%$ & $28,6 \%$ \\
\hline & NO & $85,4 \%$ & $71,4 \%$ \\
\hline \multirow{3}{*}{ Teat drying } & paper towel & $24,5 \%$ & $38,1 \%$ \\
\hline & cloth & $53 \%$ & $42,9 \%$ \\
\hline & not dry & $22,5 \%$ & $19 \%$ \\
\hline \multirow{2}{*}{$\begin{array}{c}\text { Milking } \\
\text { parlor }\end{array}$} & wood & $54,5 \%$ & $28,6 \%$ \\
\hline & masonry & $45,5 \%$ & $71,4 \%$ \\
\hline \multirow{2}{*}{$\begin{array}{l}\text { Milking } \\
\text { parlor floor }\end{array}$} & soil & $46,6 \%$ & $38,2 \%$ \\
\hline & cement floor & $53,4 \%$ & $61,9 \%$ \\
\hline
\end{tabular}

Group 1: illiterate, incomplete and complete elementary education Group 2: incomplete high school education and college education.

Concerning to milk quality analysis, the results are shown in Table 2. Not all farms were in compliance with law requirements (SCC and TBC). From all 274 MPU, 71.9\% (197) were in compliance with law requirements for SCC, whereas only $48.5 \%$ (133) were with respect to the TBC. There was a negative correlation between production and SCC $(\mathrm{r}=-0.23 ; \mathrm{n}=274 ; \mathrm{p}<0.05)$ and positive between TBC and SCC, which was $0.21(\mathrm{n}=274 ; \mathrm{p}<0.05)$.

Table 2. Quality of milk in Milk production units in Southern Brazil $(\mathrm{n}=274)$.

\begin{tabular}{lcc}
\hline \multicolumn{1}{c}{ Parameter } & $\begin{array}{c}\text { Value } \\
\text { obtained }\end{array}$ & $\begin{array}{c}\text { Value required } \\
\text { by NI-62 }\end{array}$ \\
\hline SCC (cells/mL milk) & $5.42 \times 10^{5}$ & $6 \times 10^{5}$ \\
TBC (CFU/mL milk) & $3.41 \times 10^{6}$ & $6 \times 10^{5}$ \\
Fat (\%) & 4.16 & 3 \\
Lactose (\%) & 4.36 & not determined \\
Protein (\%) & 3.39 & 2.9 \\
Total solids (\%) & 12.85 & not determined \\
\hline
\end{tabular}

SCC: Somatic cell count

TBC: Total bacterial count

NI-62: Normative Instruction No.62,
There was a positive correlation between lactose percentage and milk production $(\mathrm{r}=0.31$; $\mathrm{n}=274 ; \mathrm{p}<0.01$ ) and negative between the other components of milk production (fat, $\mathrm{r}=-0.21$; protein, $\mathrm{r}=-0.23$, total solids, $\mathrm{r}=-0.26$ ). There was a negative correlation between SCC levels and lactose content $(\mathrm{r}=-0.39 ; \mathrm{n}=274 ; \mathrm{p}<0.01)$.

\section{Discussion}

According to the 2006 Agricultural Census, 4,367,902 Brazilian existing farms, 1,089,413 are familiar type. In Southern Brazil, about 379 thousand have a family feature, and of these, 205,158 produce milk. Family farmers are responsible for $58.0 \%$ of produced milk in the country (IBGE, 2006).

Regarding the total amount of area used for dairy farming, the observed values are lower than those found in milk specialized regions, although these are also still far from reaching its potential. The low amount of produced milk is associated with the low number of lactating cows found in the study, but their yield is a factor to be considered, since management can interfere with the production of individual animals. Animal yield can be interfered by a large number of factors such as inadequate nutrition, high mastitis index and genetics (RADOSTITS, 2001).

A few number of farmers do the mastitis diagnosis when carrying out tests as CMT. Normally, reading is not correctly done and its frequency is varied. In addition, producers claim performing the alcohol test, which is made by the dairy industry, as diagnostic test for mastitis. This test checks the milk protein stability against a dehydrating agent (OLIVEIRA; TIMM, 2006).

With respect to milking infrastructure, we noted that currently the majority of producers have adapted themselves to automated milking equipment. A few years ago there were fears from the producer to acquire a mechanized milking 
equipment for the high financial investment. Nowadays, however, due to the commercial appeal and competition, the mechanized milking is necessary for ease in handling animals. However, there are still many MPU milking their animals in inadequate facilities such as wooden cowshed and dirt floors. These characteristics may impair the environment hygiene, with epidemiologically importance in the disease predisposition or to increase total bacterial count. The results show that the bacterial count of the collected milk $(3,41$ $\mathrm{x} 10^{6} \mathrm{CFU} / \mathrm{mL}$ milk) is out of compliance with legal requirements $\left(6 \times 10^{5} \mathrm{CFU} / \mathrm{mL}\right.$ milk). There were regions where MPU percentage that perform the milking in wooden facilities and on dirt floors reached $62.9 \%$ and $58.1 \%$, respectively.

In reference to pre-milking teat disinfection, only $14.2 \%$ MPU perform. What is a low percentage, given its importance. Studies indicate that this measure provides $50 \%$ reduction in the rate new infections of the mammary gland, caused by environmental pathogens and reduces the bacterial count in milk (RASMUSSEN et al., 1991; CHAPAVAL; PIEKARSKI, 2000). As for the teat drying, most people use a single common cloth for all animals, since this procedure has an important role in mastitis epidemiology because the cloth is a great pathogen spreader. In earlier study, we found that it is preferable not to use any teat drying than using a single cloth piece in all animals, since these cows present higher SCC and bacterial counts in the milk (PICOLI et al., 2014).

As the education level of the owners of milk production, the results are not promising, since in Brazil, besides the difficulty in maintaining the dairy industry, the farmer education level of the MPU determines knowledge and commitment levels in the activity (SCHNEIDER, 2009). According to the same author, the children of these farmers who intend to continue the dairy business, in general, do not complete high school and those who want to conclude their studies, do not aspire to keep the dairy business, and leave the countryside to work in another activity or attend college. For $32 \%$ of cases only parents remain working on the farm.

Low educational level affects new technology absorption and understanding of proper milking management importance, for example as seen in our observations. Data demonstrate that lack of efficiency in management and less suitable facilities for dairy production are frequently found in low education level producers, suggesting that farmer education can be an impediment for the system technification.

The Normative Instruction No. 62 (NI-62) was established since 2012, and by this standard, the SCC limits are 600 thousand cells/ milk ml for South and Southeast Brazil (BRASIL, 2011). As for TBC, the NI-62 establishes 600 thousand CFU/ milk $\mathrm{mL}$; however, it is aimed to lower this value to 100 thounsand CFU/ milk mL until 2016 (BRASIL, 2011). Despite of that, the average SCC in Southern Brazil is within these required parameters, it is very near to the limit; demonstrating that many MPUs exceed the set value. Moreover, high TBC demonstrates that one of the major resistance in milk production for Southern Brazil is management and storage, since high TBC are related to poor hygiene at dairy process. It is interesting to note that in the city with the lowest percentage of teat drying after pre-milking wash was within the law parameters (3.65 $\times 10^{5}$ cells per milk ml) and other cities where teat drying teats with cloth use is adopted, SCC is above legal parameters $\left(6.7 \times 10^{5}\right.$ cells per milk $\mathrm{ml})$. The cloth transports microorganisms from one infected individual to another. Therefore, it seems preferable not wash or dry teats when they are free of organic matter, than washing with water (procedure that spreads germs from skin surface to the teat sphincter and interior) and dry with cloth.

Costa et al. (1998) describes that high SCC levels decrease milk production, which was observed in this study by a negative correlation between these parameters. The positive correlation between SCC and TBC indicates that they simultaneously grow. 
It might mean that a large part of total bacteria in cooling tanks are from mastitis milking rooms, since SCC is an indicative of mammary gland health. Regarding the components of milk, lactose is related to the osmotic pressure regulation inside mammary glands, in a way that higher lactose production infers higher milk production (AULDIST; HUBBLE, 1998), which confirms the found positive correlation. Concerning to the other milk componentes, there was a negative correlation with production. This is due to these component dilutions in milk. In fact, it is normal that the milk solids are in lower concentrations with increasing production volume, but this does not influence, according to current legislation, the producer remuneration, who receives the produced amount by SCC and TBC (BRASIL, 2011). As to SCC, there was a negative correlation with lactose, which agrees with Gonzales et al. (2006) that studied dairy farms in same region. In cases of mastitis, the volume reduction is due to the epitelial cell lesion, reducing lactose yield.

According to IBGE (2011), milk production in Brazil has been growing steadily and, in the period from 1990 to 2009, increased 100.94\%. In Southern Brazil, Rio Grande do Sul State, showed an increase in milk production performance by $134.2 \%$ in the same period; and this State had more involvement in Southern Brazil production (37.88\%); followed by Paraná (37.2\%) and Santa Catarina (24.93\%). This demonstrates the great potential of Souther Brazil in the dairy chain, since even with the lack of infrastructure and technical knowledge, it has yearly increased. If some harmful factors were circumvented, there would be benefit in milk quality and also in the produced amount, adding value to products benefiting farmers, the dairy industry and also the final consumer.

\section{Conclusions}

According to the technical visits and questionnaire test results and milk chemical analyzes, we observed farmers that do not invest in production and work the same way for decades. The education level of them seems to contribute to adopt improved production techniques in the farms, enhancing production rates. Data demonstrated that inadequate management are more practiced by lower education level producers, and for these properties, there is production of low quality milk.

\section{References}

AULDIST, M. J.; HUBLLE, I. B. Effects of mastitis on raw milk and dairy products. Australian Journal of Dairy Technology, Melbourne, v. 53, n. 1, p. 28-36, 1998.

BALBINOT JUNIOR, A. A.; MORAES, A.; VEIGA, M.; PELISSARI, A.; DIECKOW, J. Integração lavourapecuária: intensificação de uso de áreas agrícolas. Ciência Rural, Santa Maria, v. 39, n. 6, p. 1925-1933, 2009.

BRASIL. Ministério da Agricultura, Pecuária e Abastecimento. Instrução Normativa $\mathrm{n}^{0}$ 62, de 29 de dezembro de 2011. Aprova o regulamento técnico de produção, identidade e qualidade do leite tipo A, o regulamento técnico de identidade e qualidade de leite cru refrigerado, o regulamento técnico de identidade e qualidade de leite pasteurizado e o regulamento técnico da coleta de leite cru refrigerado e seu transporte a granel, em conformidade com os anexos desta instrução normativa. Diário Oficial [da] República Federativa do Brasil, Brasília, 31 dez. de 2011. Seção 1, p. 6.

Ministério da Agricultura, Pecuária e Abastecimento. Projeções do Agronegócio: Brasil 2012/2013 a 2022/2023. Brasília: Mapa/ACS, 2013. 96 p.

BRITO, M. A. V. P.; BRITO, J. R. F.; PORTUGAL, J. A. B. Identificação de contaminantes bacterianos no leite cru de tanques de refrigeração.Revista do Instituto de Laticínios "Cândido Tostes", Juíz de Fora, v. 57, n. 1, p. 83-88, 2002.

CHAPAVAL, L.; PIEKARSKI, P. R. B. Leite de qualidade: manejo reprodutivo, nutricional e sanitário. Viçosa: Aprenda Fácil, 2000. 195 p.

COSTA, E. O.; RIBEIRO, A. R.; WATANABE, E. T.; GARINO JUNIOR, F.; SILVA, J. A. B.; THIERS, F. O. Avaliação in vitro dos desinfetantes utilizados na pós ordenha (teatdipping) para controle da mastite bovina. Revista Napgama, São Paulo, v. 1, n. 1, p. 18-22, 1998.

GONZALES, H. L.; FISCHER, V.; RIBEIRO, M. E. R.; STUMPF, W.; GOMES, J. F.; FAGUNDES, C. M.; 
SILVA, M.A. Comparação da qualidade do leite em diferentes sistemas de produção da bacia leiteira de Pelotas, RS. Revista Brasileira de Agrociência, Pelotas, v. 12, n. 4, p. 475-482, 2006.

INSTITUTO BRASILEIRO DE GEOGRAFIA E ESTATÍSTICA - IBGE. Censo Agropecuário 2006, resultados preliminares. Rio de Janeiro: IBGE, 2006. v. 1, 146 p. Disponível em: <http://www.ibge.gov.br/home/ estatistica/economia/agropecuaria/censoagro/2006/ agropecuario.pdf>. Acesso em: 04 dez. 2013.

Estatística da produção pecuária, junho de 2014. Rio de Janeiro. IBGE, 2014. 49 p. Disponível em: <http://ibge.gov.br/home/estatistica/indicadores/ agropecuaria/producaoagropecuaria/abate-leite-couroovos_201401_publ_completa.pdf>. Acesso em: $14 \mathrm{dez}$. 2014.

Sistema IBGE de Recuperação Automática $\overline{\operatorname{SIDRA}}$, 2011. Disponível em: <http://www.sidra.ibge. gov.br>. Acesso em: 05 dez. 2013.

KUMAR, A.; RAHAL, A.; DWIVEDI, S. K.; GUPTA, M. K. Bacterial prevalence and antibiotic resistance profile from bovine mastitis in Mathura, India. Egyptian Journal of Dairy Science, Cairo, v. 38, n. 1, p. 31-34, 2010.

OLECHNOWWICZ, J.; JASKOWSKI, M. Somatic cells count in cow's bulk tank milk. The Journal of Veterinary Medical Science, Tokyo, v. 74, n. 6, p. 681-686, 2012.
OLIVEIRA, D. S.; TIMM, C. D. Composição do leite com instabilidade da caseína. Revista Ciência e Tecnologia de Alimentos, Campinas, v. 26, n. 2, p. 259-263, 2006.

PICOLI, T.; ZANI, J. L.; BANDEIRA, F. S.; ROLL, V. F. B.; RIBEIRO, M. E. R.; VARGAS, G. D.; HÜBNER, S. O.; LIMA, M.; MEIRELES, M. C. A.; FISCHER, G. Manejo de ordenha como fator de risco na ocorrência de micro-organismos em leite cru. Semina: Ciência Agrárias, Londrina, v. 35, n. 4, p. 1425-1434, 2014.

RADOSTITS, O. M. Herd health food animal production medicine. $3^{\text {th }}$ ed. Philadelphia, USA: W.B. Saunders Company, 2001.608 p.

RASMUSSEN, M. D.; GALTON, D. M.; PETERSSON L. G. Effects of premilking teat preparation on spores of anaerobies bacterias and iodine residues in milk. Journal of Dairy Science, Champaign, v. 74, n. 8, p. 24722478, 1991.

SAS INSTITUTE. SAS/Statuser's guide. Version 9.1. Cary: SAS Institute, 2004.

SCHNEIDER, S. A pluriatividade na agricultura familiar. Porto Alegre: UFRGS, 2003. 254 p.

. A diversidade da agricultura familiar. Porto Alegre: UFRGS, 2009. 295 p.

SCHULTZ, L. H. Somatic cells in milk physiological aspects and relationship to amount and composition of milk. Journal of Food Protection, Des Moines, v. 40, n. 2, p. 125-131, 1977. 
